Article

\title{
Strain-Dependent Cheese Spoilage Potential of Clostridium tyrobutyricum
}

\author{
Lucija Podrzaj ${ }^{1,2}$, Johanna Burtscher ${ }^{1, * \mathbb{C}}$, Franziska Küller ${ }^{1,2}$ and Konrad J. Domig ${ }^{1 \mathbb{C}}$ \\ 1 Institute of Food Science, University of Natural Resources and Life Sciences Vienna (BOKU), \\ 1190 Vienna, Austria; lucija.podrzaj@boku.ac.at (L.P.); franziska@kueller.eu (F.K.); \\ konrad.domig@boku.ac.at (K.J.D.) \\ 2 Austrian Competence Centre for Feed and Food Quality, Safety and Innovation (FFoQSI GmbH), \\ Technopark 1C, 3430 Tulln, Austria \\ * Correspondence: johanna.burtscher@boku.ac.at; Tel.: +43-1-47654-75456
}

Received: 20 October 2020; Accepted: 19 November 2020; Published: 22 November 2020

\begin{abstract}
Clostridium tyrobutyricum, a Gram-positive, anaerobic, spore-forming bacterium, is considered as one of the main causative agents for spoilage of hard and semihard cheeses. Growth of $C$. tyrobutyricum in cheese is critically influenced by ripening temperature and time, $\mathrm{pH}$, salt and lactic acid concentration, moisture and fat content, and the presence of other microorganisms. Previous studies revealed high intraspecies diversity of $C$. tyrobutyricum strains and variable tolerance toward $\mathrm{pH}$, temperatures, and salt concentrations. These findings indicate that strain-dependent characteristics may be relevant to assess the risk for cheese spoilage if clostridial contamination occurs. In this study, we aimed to compare the phenotypes of 12 C. tyrobutyricum strains which were selected from 157 strains on the basis of genotypic and proteotypic variability. The phenotypic analysis comprised the assessment of gas production and organic acid concentrations in an experimental cheese broth incubated at different temperatures $\left(37,20\right.$, and $\left.14^{\circ} \mathrm{C}\right)$. For all tested strains, delayed gas production at lower incubation temperatures and a strong correlation between gas production and the change in organic acid concentrations were observed. However, considering the time until gas production was visible at different incubation temperatures, a high degree of heterogeneity was found among the tested strains. In addition, variation among replicates of the same strain and differences due to different inoculum levels became evident. This study shows, that, among other factors, strain-specific germination and growth characteristics should be considered to evaluate the risk of cheese spoilage by $C$. tyrobutyricum.
\end{abstract}

Keywords: Clostridium tyrobutyricum; spore; spoilage; late blowing; cheese

\section{Introduction}

The contamination of cheese milk with endospores of butyric acid-producing clostridia represents a major concern for cheese producers. Although milk does not provide suitable growth conditions, clostridial endospores may encounter favorable conditions for germination and outgrowth during ripening of hard and semihard cheese. This metabolic activity leads to pronounced cheese spoilage [1]. The production of excessive amounts of gas and butyric acid during growth results in blown cheeses of inferior sensory quality and financial losses for producers [2]. Several clostridial species, mainly Clostridium tyrobutyricum, Clostridium butyricum, Clostridium sporogenes, and Clostridium beijerinckii, have been isolated from blown cheese. The species $C$. tyrobutyricum is considered to be the primary cause of severe late blowing defects (LBD) [3-6]. Among strains of this species, however, significant differences have been observed. On the one hand, genetic heterogeneity has been illustrated using strain typing methods; on the other hand, some studies characterized phenotypic variation among C. tyrobutyricum 
strains [7-9]. For instance, Silvetti et al. demonstrated that $\mathrm{pH}$, salt concentrations, and temperature can affect spore germination, growth, gas production, and reduction potential of vegetative cells and spores of clostridia in an enriched milk medium [10]. They observed that a temperature below $15^{\circ} \mathrm{C}$ prevented the gas production by vegetative cells, while a combination of temperature, $\mathrm{pH}$, and salt concentration was needed to prevent germination of spores and subsequent gas production. Moreover, Ruusunen et al. observed varying tolerance to changes of $\mathrm{pH}$, temperature, and salt concentrations among 10 C. tyrobutyricum strains in tryptone-peptone-glucose-yeast extract and reinforced clostridial broth [11]. Garde et al. concluded that the production of gas and butyric acid in milk and Bryant and Burkey medium (BB) seems to be strain-dependent [12]. The results obtained in the course of these previous studies raised further questions about the cheese spoilage potential of $C$. tyrobutyricum. Does the genetic diversity among the strains reflect phenotypic diversity and vice versa? If the spoilage potential is strain-dependent, can the same behavior of a strain be expected in repeated experiments? To the best of our knowledge, these issues have not been specifically addressed in previous studies. Hence, the aim of this study was to further elucidate the strain-dependent cheese spoilage potential of C. tyrobutyricum. For this purpose, we assessed the genetic diversity of 157 clostridial strains. A subset of 11 genetically distinct strains and the type strain were selected for phenotypic analyses by assessing gas and organic acid production at different incubation temperatures in an experimental cheese broth.

\section{Materials and Methods}

\subsection{Assessment of the Genetic and Proteotypic Diversity of the Test Strain Set}

A total of 157 C. tyrobutyricum strains of the culture collection of the Institute of Food Science of the University of Natural Resources and Life Sciences Vienna were used in this study. The strain set included four strains from the German Collection of Microorganisms and Cell Cultures, i.e., DSM 2637 (type strain; named Cl_20 in this study), DSM 663 (Cl_14), DSM 664 (Cl_15), and DSM 1460 (Cl_2), three strains isolated from NIZO strain BZ 15 (Cl_25, Cl_29, and Cl_51), three strains from Agroscope in Switzerland, i.e., FAM1559 (Cl_33), FAM25158 (Cl_52), and FAM25159 (Cl_53), 83 strains that were isolated from 27 spoiled cheese samples from eight production locations (named A-H) [6], and 64 isolates from 64 raw milk samples collected from three production locations (named A-C) [13]. First, the diversity among the 157 strains of $C$. tyrobutyricum was assessed using MALDI-TOF MS (matrix-assisted laser desorption ionization-time of flight mass spectrometry) and hexaplex-PCR typing according to the procedures described by Burtscher et al. [8]. Data preprocessing and UPGMA (unweighted paired-group method with arithmetic mean) clustering were performed using the software BioNumerics v7.6.3. (Applied Maths, Ghent, Belgium).

According to the genotypic and proteotypic results, 12 representative strains were selected for further phenotypic analyses. A description of the strain selection process is provided in Section 3.1. An overview of the 12 selected C. tyrobutyricum strains is presented in Table 1.

Table 1. Clostridium tyrobutyricum strains used in this study.

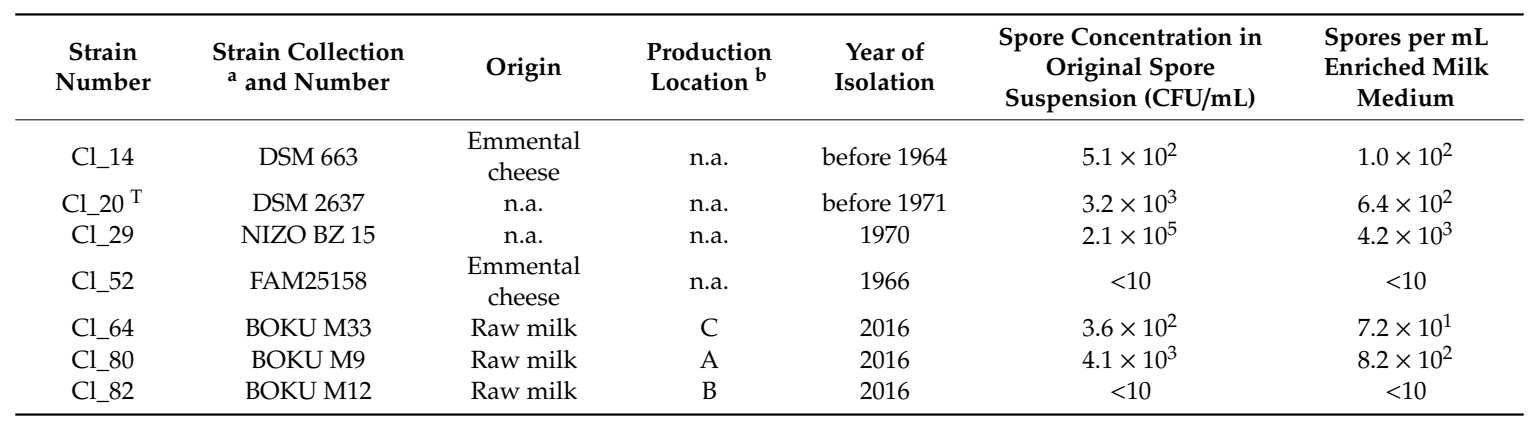


Table 1. Cont.

\begin{tabular}{|c|c|c|c|c|c|c|}
\hline $\begin{array}{l}\text { Strain } \\
\text { Number }\end{array}$ & $\begin{array}{l}\text { Strain Collection } \\
{ }^{a} \text { and Number }\end{array}$ & Origin & $\begin{array}{l}\text { Production } \\
\text { Location }^{b}\end{array}$ & $\begin{array}{l}\text { Year of } \\
\text { Isolation }\end{array}$ & $\begin{array}{l}\text { Spore Concentration in } \\
\text { Original Spore } \\
\text { Suspension }(\mathrm{CFU} / \mathrm{mL})\end{array}$ & $\begin{array}{l}\text { Spores per } \mathrm{mL} \\
\text { Enriched Milk } \\
\quad \text { Medium }\end{array}$ \\
\hline $\mathrm{Cl} \_84$ & BOKU M17 & Raw milk & B & 2016 & $7.0 \times 10^{4}$ & $1.4 \times 10^{3}$ \\
\hline Cl_171 & BOKU K13 & $\begin{array}{l}\text { Semihard } \\
\text { cheese }\end{array}$ & G & 2015 & $9.5 \times 10^{4}$ & $1.9 \times 10^{3}$ \\
\hline Cl_188 & BOKU K47 & $\begin{array}{c}\text { Cheese-sausage } \\
\text { mixture }\end{array}$ & E & 2015 & $7.6 \times 10^{3}$ & $1.5 \times 10^{3}$ \\
\hline
\end{tabular}

${ }^{a}$ DSM, Deutsche Sammlung von Mikroorganismen und Zellkulturen GmbH (German Collection of Microorganisms and Cell Cultures), Braunschweig, Germany; NIZO, NIZO food research, Ede, The Netherlands; BOKU, University of Natural Resources and Life Sciences Vienna, Austria. ${ }^{\mathrm{b}}$ Letters representing different production locations. ${ }^{\mathrm{T}}$ Type strain. CFU, colony-forming units; n.a., data not available.

\subsection{Spore Suspension Production and Cultivation Conditions}

C. tyrobutyricum strains were isolated from cryo-cultures and inoculated into $5 \mathrm{~mL}$ of reinforced clostridial medium (RCM: $10 \mathrm{~g}$ of meat extract, $10 \mathrm{~g}$ of tryptone, $3 \mathrm{~g}$ of yeast extract, $10 \mathrm{~g}$ of $\mathrm{D}-(+)$-glucose anhydrous, $1 \mathrm{~g}$ of starch, $5 \mathrm{~g}$ of sodium chloride, $3 \mathrm{~g}$ of sodium acetate, and $0.5 \mathrm{~g}$ of L-cysteine hydrochloride monohydrate per liter) and incubated for $72 \mathrm{~h}$ at $37^{\circ} \mathrm{C}$ in anaerobic jars (using a gas mixture containing $80 \% \mathrm{~N}_{2}, 10 \% \mathrm{CO}_{2}$, and $10 \% \mathrm{H}_{2}$; Don Whitley Scientific, West Yorkshire, UK). Then, spore suspensions were produced in triplicate as follows: $1 \mathrm{~mL}$ of the grown C. tyrobutyricum culture was inoculated into a tube containing $40 \mathrm{~mL}$ of peptone yeast glucose broth (PYG: $20 \mathrm{~g}$ of tryptone, $10 \mathrm{~g}$ of yeast extract, $10 \mathrm{~g}$ of $\mathrm{D}-(+)$-glucose anhydrous, $0.4 \mathrm{~g}$ of sodium bicarbonate, $0.04 \mathrm{~g}$ of monopotassium phosphate, $0.04 \mathrm{~g}$ of dipotassium phosphate, $0.008 \mathrm{~g}$ of L-cysteine hydrochloride monohydrate, $0.008 \mathrm{~g}$ of magnesium sulfate heptahydrate, $0.01 \mathrm{~g}$ of hemin, and $0.01 \mathrm{~g}$ of vitamin $\mathrm{K} 1$ per liter) and incubated for 10 days at $30^{\circ} \mathrm{C}$ under anaerobic conditions using the gas mixture described above. After pasteurization at $80^{\circ} \mathrm{C}$ for $20 \mathrm{~min}$ in a water bath, the tubes were incubated for 3 more days at $30^{\circ} \mathrm{C}$ under anaerobic conditions. After a centrifugation step $\left(1300 \times g, 15 \mathrm{~min}, 4^{\circ} \mathrm{C}\right)$, spore pellets were washed by resuspending them in $10 \mathrm{~mL}$ of sterile deionized water and centrifuged again at the same conditions. The washing procedure and centrifugation were repeated twice. The resulting spore pellets were resuspended in $10 \mathrm{~mL}$ of sterile deionized water. Spore production and growth was checked under the microscope after spore staining using the dyes crystal violet and safranin. Afterward, the three spore suspensions of a strain were combined into one tube and pasteurized at $80^{\circ} \mathrm{C}$ for $20 \mathrm{~min}$.

To determine the spore count, spore suspensions and decimal dilutions thereof were plated in duplicate on reinforced clostridial agar (RCA, Merck, Germany) and incubated at $37^{\circ} \mathrm{C}$ under anaerobic conditions. After 7 days, colonies were counted and expressed as colony-forming units (CFU) per $\mathrm{mL}$ (Table 1). To confirm the assignment to the species $C$. tyrobutyricum, three grown colonies were randomly selected and identified using MALDI-TOF mass spectrometry (MS), using a Microflex LT instrument and MALDI Biotyper software (Bruker Daltonik, Bremen, Germany) according to the manufacturer's instructions. The presence of spores was visualized and captured by phase-contrast microscopy using an Olympus BX41 (Olympus, Tokyo, Japan) microscope with a phase-contrast objective (Figure S1, Supplementary Materials). Magnification was accomplished with a $100 \times$ oil immersion objective and 10x ocular magnification, resulting in a total magnification of 1000×.

\subsection{Growth and Gas Production at Different Temperatures}

For the assessment of growth and gas production, an enriched milk medium (EM) described by Silvetti et al. was adapted to create growth conditions that are similar to the circumstances present during ripening of typical Austrian hard cheese and other hard cheese types that are usually affected by clostridia $[10,14-17]$. In brief, we aimed for a medium containing sodium lactate and acetate as carbon sources, $1 \%$ sodium chloride, with a $\mathrm{pH}$ of 5.4 . For this purpose, reconstituted skim milk (100 $\mathrm{g}$ 
per liter) was supplemented with $10 \mathrm{~g}$ of yeast extract, $56 \mathrm{~g}$ of sodium lactate $(60 \% \mathrm{w} / \mathrm{w}), 10 \mathrm{~g}$ of sodium acetate, $10 \mathrm{~g}$ of sodium chloride, and $2 \mathrm{~g}$ of $\mathrm{L}$-cysteine per liter. The $\mathrm{pH}$ value of the medium was adjusted to 5.4 using sterile filtered $1 \mathrm{~N} \mathrm{HCl}$.

Before inoculation, if necessary, spore suspensions were diluted to reach final concentrations from $10^{2}$ to $10^{3}$ spores per $\mathrm{mL}$ of EM. Three strains were prepared in three different concentrations $\left(10^{2}, 10^{3}\right.$, and $10^{4}$ spores per $\mathrm{mL}$ of EM), in order to specifically examine the influence of spore concentration. Next, nine aliquots of $1 \mathrm{~mL}$ of each spore suspension were centrifuged $\left(1300 \times \mathrm{g}\right.$, for $15 \mathrm{~min}$, at $\left.4^{\circ} \mathrm{C}\right)$ and pellets were resuspended in $1 \mathrm{~mL}$ of prepared EM. Resuspended pellets were added to glass tubes containing $4 \mathrm{~mL}$ EM. To generate anaerobic conditions, the tubes were sealed with a plug consisting of $2.5 \mathrm{~mL}$ of melted Vaseline-paraffin. Blank controls were prepared with no spores added, but were otherwise subjected to the same process as the experimental tubes. In the next step, the tubes were subjected to a heat treatment, which resembles the procedure used in Austrian hard cheese production [15]. During the first step, the tubes were heated at $32{ }^{\circ} \mathrm{C}$ for $90 \mathrm{~min}$ in a water bath, corresponding to conditions under which rennet coagulation occurs. Then, the water bath was heated to $52{ }^{\circ} \mathrm{C}$ and the temperature was held for additional $20 \mathrm{~min}$ at $52{ }^{\circ} \mathrm{C}$, mimicking the scalding step. Lastly, the tubes were cooled down to room temperature.

Gas production and changes in the EM by clostridial spores were evaluated at three different temperatures: 37,20 , and $14{ }^{\circ} \mathrm{C}$. The temperature of $37^{\circ} \mathrm{C}$ represents the optimal growth temperature of clostridia [18]. The second temperature of $20^{\circ} \mathrm{C}$ was chosen according to the production process of Swiss Emmental cheese, in which the cheese is first ripened at a temperature of $\sim 20-24{ }^{\circ} \mathrm{C}$ for a certain period of time, and then stored at $10-13^{\circ} \mathrm{C}$ [19]. Lastly, the temperature of $14^{\circ} \mathrm{C}$ was chosen according to ripening temperatures of Austrian mountain cheese such as Vorarlberger Bergkäse and Tiroler Bergkäse $[15,16]$. Clostridial spores of each strain were incubated at each temperature in triplicate.

During incubation, the tubes were inspected daily for gas production by observing the plug displacement. When, within a set incubated at the same temperature, at least six out of 12 strains showed gas production in at least one replicate, the incubation was interrupted. At $14{ }^{\circ} \mathrm{C}$, however, only four out of 12 strains showed gas production after an incubation of 120 days. Considering the minimum ripening time of 3 months for Austrian mountain cheese, the samples were analyzed at this time point [15]. The tubes were photographed, and the lifted plug height was measured with a ruler. Consequently, $2 \mathrm{~mL}$ of the test liquid was harvested from each tube and destined to chemical analysis. The incubation of tubes without gas production was continued until gas production occurred or until the end of the incubation period $\left(37^{\circ} \mathrm{C}: 150\right.$ days; $20^{\circ} \mathrm{C}$ and $14^{\circ} \mathrm{C}: 170$ days).

\subsection{Chemical Analysis}

The $\mathrm{pH}$ values of harvested test liquids were determined in duplicate using a pH meter Lab 845 (SI Analytics, Mainz, Germany) equipped with an N 6000 BNC electrode (SI Analytics, Mainz, Germany).

Concentrations of organic acids (lactic, acetic, propionic, and butyric acid) in harvested test liquids were determined by high-performance liquid chromatography (HPLC). Cell-free supernatants were prepared from harvested test liquids by centrifugation at $6000 \times \mathrm{g}$ for $15 \mathrm{~min}$ at $4{ }^{\circ} \mathrm{C}$. To achieve better precipitation, $150 \mu \mathrm{L}$ of Carrez solution I (15 g of potassium hexacyanoferrate(II) trihydrate dissolved in $100 \mathrm{~mL}$ of distilled water) and $150 \mu \mathrm{L}$ Carrez solution II (30 g of zinc sulfate heptahydrate diluted to $100 \mathrm{~mL}$ distilled water) were added to the test liquid, and then the tubes were centrifuged at 15,000× $g$ for $30 \mathrm{~min}$ at $4{ }^{\circ} \mathrm{C}$. The supernatant was filtered through a $0.2 \mathrm{~mm}$ nylon membrane filter (Carl Roth, Karlsruhe, Germany) and stored at $-20^{\circ} \mathrm{C}$ until use. Before the HPLC measurement, prepared supernatants were thawed at room temperature, heated for $5 \mathrm{~min}$ at $99^{\circ} \mathrm{C}$, and centrifuged at $16,000 \times g$ for $10 \mathrm{~min}$. Supernatants were transferred into a fresh tube. The samples were injected (volume $20 \mu \mathrm{L}$ ) and eluted with $2.5 \mathrm{mM}$ sulfuric acid at $60{ }^{\circ} \mathrm{C}$ and a flow rate of $0.5 \mathrm{~mL} \cdot \mathrm{min}^{-1}$ on a $300 \times 7.8 \mathrm{~mm}$ ion exchange column HPX-87H Aminex (Bio-Rad, Veenedaal, The Netherlands) in a HPLC system (Dionex Ultimate 3000, Thermo Fisher, Dreieich, Germany), consisting of a WPS-3000 Well-plate autosampler, an LPG-3600 gradient pump, an RS column oven, and a Rapid Separation Diode Array detector at 
$210 \mathrm{~nm}$ for lactic, acetic, propionic, and butyric acid. The HPLC was controlled using the Chromeleon ${ }^{\circledR}$ Software (Version 7.2, Thermo Fisher Scientific, Dreieich, Germany). For obtaining the calibration curves, a mixture of the standards of selected concentrations was injected into HPLC. After injection of the samples, chromatographic peaks were identified by comparing the retention times of the sample with those of the known standards. Results were expressed as net production with respect to the organic acid content in EM (blank control).

\subsection{Statistics}

Statistical analysis of data was performed by means of SPSS software (version 24, SPSS Inc. Chicago, IL, USA). Shapiro-Wilk's test was used to verify normality and Levene's test was used to verify homogeneity of variances. Spearman's correlation coefficients were obtained to investigate potential linear correlations among $\mathrm{pH}$, organic acids, and gas production. Student's $t$-test was used to detect significant differences among isolates. Comparison of means of $\mathrm{pH}$ was carried out by Tukey's test, with significance assigned at $p<0.05$.

\section{Results and Discussion}

\subsection{Genotypic and Proteotypic Diversity}

The obtained dendrograms in Figure 1 illustrate the diversity of the 157 clostridial strains in a circular layout on the basis of the spectra obtained using MALDI-TOF MS (a) and band patterns obtained using hexaplex-PCR (b). Twelve representative strains were selected for further phenotypic analyses. For the selection, the samples in each dendrogram were grouped into clusters. At similarity levels of $80 \%$, the strains grouped into 11 clusters according to their hexaplex-PCR band patterns and into five clusters according to their protein spectra. The lower diversity observed among the MALDI-TOF MS spectra compared to hexaplex-PCR band patterns is consistent with results obtained in a previous study by Burtscher et al. [8]. Generally, the dendrograms obtained using the two typing methods yielded different arrangements of strains. However, some congruence was observed between the two methods. Strains Cl_52 and Cl_84, for instance, clustered separately from other strains in both typing analyses and, therefore, were selected for further assessment of gas and organic acid production. In contrast, the type strain $\mathrm{Cl} \_20$ and strain $\mathrm{Cl} \_29$ were indistinguishable using hexaplex-PCR and also showed similar protein spectra. Hence, $\mathrm{Cl} \_20$ and $\mathrm{Cl} \_29$ were selected as representative samples of similar strains. Subsequently, the dendrograms were screened for strains which were evenly distributed across the clusters in both dendrograms. Afterward, the metadata of the remaining strains were checked, and the sample set was finally narrowed down to a subset of 12 strains, which included the type strain (Cl_20 or DSM 2637) and strains, which were isolated at various sampling times from different food sources (cheese types and raw milk) and different production locations. 
a)

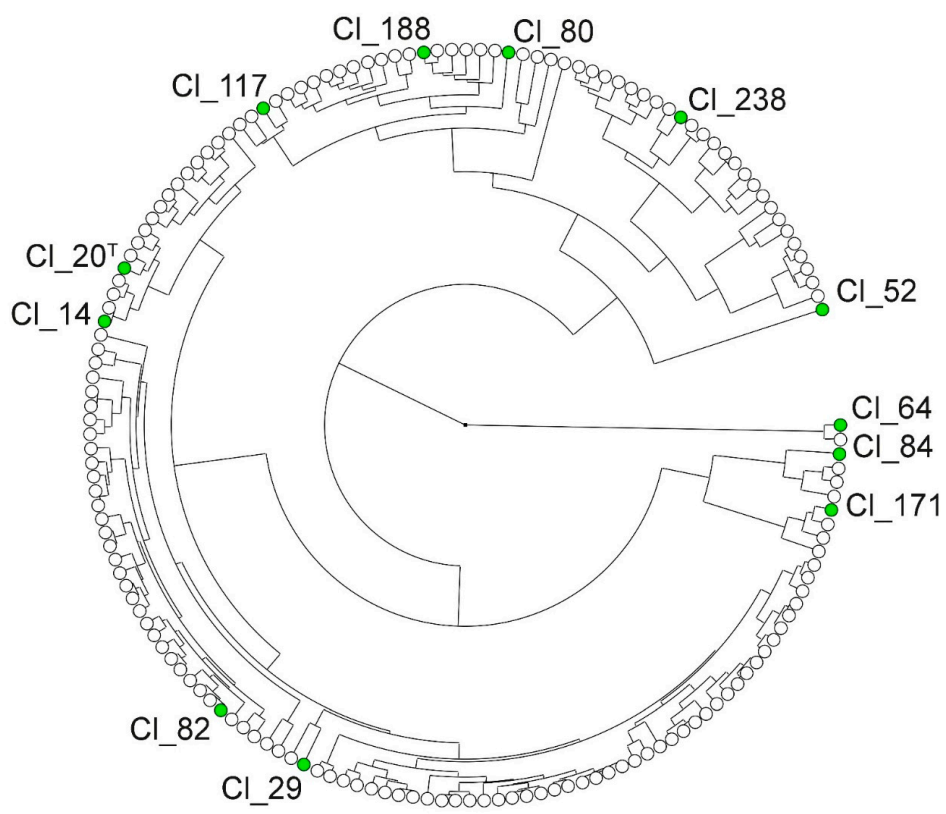

b)

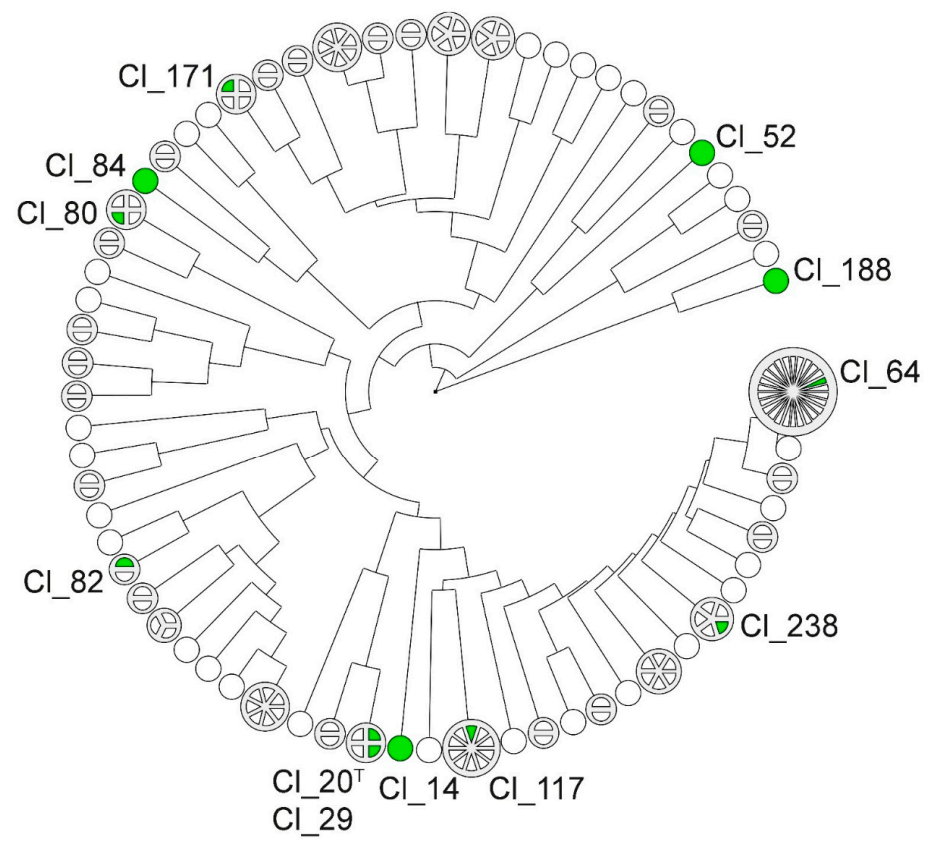

Figure 1. Dendrograms based on matrix-assisted laser desorption ionization-time of flight mass spectrometry (MALDI-TOF MS) spectra (a) and hexaplex-PCR band patterns (b) in a circular layout. The dendrogram was constructed using the unweighted paired-group method with arithmetic mean (UPGMA). The branch length indicates similarity between different strains and clusters. Each disc symbolizes a strain. Strains that yielded $100 \%$ similarity in the cluster analysis were aggregated into larger discs containing segments for each strain $(\mathbf{b})$. Strains that were selected for phenotypic analyses are marked in green. ${ }^{\mathrm{T}}$ Type strain. 


\subsection{Gas Production}

Gas is one of the major products of butyric acid fermentation, causing swelling, cracks, slits, and irregular eye formation in hard and semihard cheeses [1]. Table 2 provides the number of days until gas production by $C$. tyrobutyricum strains was observed in EM at incubation at 37, 20, and $14{ }^{\circ} \mathrm{C}$. Ten and 11 out of 12 strains were able to produce gas at 37 and $20^{\circ} \mathrm{C}$, respectively. For all strains (except for $\mathrm{Cl} \_64$ at $37^{\circ} \mathrm{C}$ ) at 37 and $20^{\circ} \mathrm{C}$, the results coincided insofar as all three replicates of one strain were either positive or negative. At $14{ }^{\circ} \mathrm{C}$, four out of 12 strains produced gas. In contrast to the higher temperatures, only one strain, namely, $\mathrm{Cl} \_84$, showed gas production in all replicates. The average time span between inoculation and observed gas production was $5.5 \pm 2.4$ days at $37^{\circ} \mathrm{C}$, $30.8 \pm 10.3$ days at $20^{\circ} \mathrm{C}$, and $108.2 \pm 21.4$ days at $14^{\circ} \mathrm{C}$. Although the temperature of $14^{\circ} \mathrm{C}$ inhibited gas production of most of the strains, it did not entirely prevent gas production. It is evident, however, that lower incubation temperatures delayed the gas production of C. tyrobutyricum in EM. Previous in vitro studies also reported the influence of low ripening temperatures on C. tyrobutyricum [10,11]. However, Silvetti et al. reported a lower number of days until gas production was obvious under similar conditions [10]. This can be explained by the higher number of spores that were inoculated $\left(10^{5}\right.$ to $\left.10^{7}\right)$. Ruusunen et al. observed that a temperature lower than $10^{\circ} \mathrm{C}$ inhibited the growth and gas production of some C. tyrobutyricum strains [11]. The influence of lowering storage temperatures on the gas formation of other clostridia, such as C. sporogenes and C. beijerinckii, in culture media and cheese has also been reported [10,20]. In a recent study, Morandi et al. reported a decrease of the presence of $C$. tyrobutyricum spores and consequent late blowing defects in Valtellina Casera PDO (protected designation of origin) cheese during aging at $8{ }^{\circ} \mathrm{C}$, while growth was observed at $13^{\circ} \mathrm{C}[21]$.

Table 2. Numbers of days of incubation required to observe a plug displacement greater than $0.5 \mathrm{~cm}$ caused by gas production of $C$. tyrobutyricum strains in enriched milk medium (EM) during anaerobic incubation at $37^{\circ} \mathrm{C}$ for 150 days, and at 20 and $14{ }^{\circ} \mathrm{C}$ for 170 days.

\begin{tabular}{|c|c|c|c|}
\hline \multirow{2}{*}{ Strain } & \multicolumn{3}{|c|}{ Temperature } \\
\hline & $37^{\circ} \mathrm{C}$ & $20^{\circ} \mathrm{C}$ & $14^{\circ} \mathrm{C}$ \\
\hline \multirow[t]{3}{*}{ Cl_14 } & 5.5 & 23.7 & - \\
\hline & 3.3 & 22.8 & - \\
\hline & 4 & 22.8 & - \\
\hline \multirow[t]{3}{*}{ Cl_20 ${ }^{\mathrm{T}}$} & 3.3 & 39.7 & - \\
\hline & 3.4 & 34.8 & - \\
\hline & 4.7 & 38.6 & - \\
\hline \multirow[t]{3}{*}{ Cl_29 } & 3.8 & 48.7 & - \\
\hline & 5.9 & 70.3 & - \\
\hline & 5.4 & 47 & - \\
\hline \multirow[t]{3}{*}{ Cl_52 } & - & - & - \\
\hline & - & - & - \\
\hline & - & - & - \\
\hline \multirow[t]{3}{*}{ Cl_64 } & 5.8 & 25.9 & 107.2 \\
\hline & 12.9 & 40 & - \\
\hline & - & 34.8 & - \\
\hline \multirow[t]{3}{*}{ Cl_80 } & 4.8 & 21.9 & - \\
\hline & 6.3 & 22.9 & 115.8 \\
\hline & 7.4 & 26.8 & 73.8 \\
\hline \multirow[t]{3}{*}{ Cl_82 } & - & 39 & - \\
\hline & - & 43.8 & - \\
\hline & - & 27.7 & - \\
\hline
\end{tabular}


Table 2. Cont.

\begin{tabular}{cccc}
\hline \multirow{2}{*}{ Strain } & \multicolumn{3}{c}{ Temperature } \\
\cline { 2 - 4 } & $\mathbf{3 7}{ }^{\circ} \mathbf{C}$ & $\mathbf{2 0}{ }^{\circ} \mathbf{C}$ & $\mathbf{1 4}{ }^{\circ} \mathbf{C}$ \\
\hline Cl_84 & 3.5 & 27.4 & 115.3 \\
& 3.5 & 32.6 & 147.7 \\
& 4.2 & 26.8 & 115.3 \\
\hline Cl_117 & 7.6 & 27.7 & - \\
& 8.5 & 23.8 & - \\
\hline Cl_171 & 10.5 & 26 & - \\
& 3.4 & 22.1 & - \\
& 3.5 & 22.6 & - \\
\hline Cl_188 & 3.4 & 27.4 & - \\
& 7.5 & 22.6 & - \\
\hline Cl_238 & 7.9 & 23.9 & 109.7 \\
& 8.3 & 26.4 & - \\
\hline & 3.7 & 25.9 & - \\
\hline & 3.3 & 26.8 & \\
\hline
\end{tabular}

Interestingly, all replicates of 11 out of 12 strains were able to produce gas at $20^{\circ} \mathrm{C}$, suggesting that the tested $C$. tyrobutyricum strains may have adapted to lower temperatures in the dairy environment (i.e., dairy farm environment, conditions during cheese ripening and storage).

The ability of $C$. tyrobutyricum spores to produce gas even at low ripening temperatures emphasizes the importance of precise control of ripening conditions during cheese manufacture. This finding may be important in the production of traditional raw milk cheese. Of particular importance are some PDO cheese types, for which silage feeding is often prohibited and a traditional production process is required. Moreover, for these cheeses, physical treatments and additives used against clostridial spores are often prohibited [22]. For other cheeses, however, clostridial spores may be reduced via centrifugation or microfiltration of the cheese milk, whereas the addition of nitrate, lysozyme, bacteriocins, or jenny milk may hamper germination and outgrowth of clostridia [23-29].

\subsection{Organic Acid Concentrations and $p H$ Values}

Organic acids are important characteristics associated with cheese manufacture and ripening, and, hence, with final cheese composition and quality [30]. Organic acid production may arise in cheese as a result of hydrolysis of milk fat during lipolysis, metabolism of residual lactose, citrate, and lactate, and bacterial growth [31]. Information on the changes in organic acid concentrations is important for the understanding of bacterial metabolism. Figure 2 depicts changes in organic acid concentrations in EM inoculated with different $C$. tyrobutyricum strains. The butyric acid concentration was negatively correlated with lactic acid concentration $(r=-0.680)$. C. tyrobutyricum produces butyric acid from lactic acid via the Embden-Meyerhof-Parnas pathway. The fermentation pathway results in $1 \mathrm{~mol}$ of butyric acid, $2 \mathrm{~mol}$ of $\mathrm{H}_{2}$, and $2 \mathrm{~mol}$ of $\mathrm{CO}_{2}$ per $2 \mathrm{~mol}$ of lactic acid [32]. Hence, it is not surprising that the butyric acid concentration was positively correlated with gas production $(r=0.860)$. A similar observation was reported by Driehuis et al. for BB medium inoculated with C. tyrobutyricum strains [33]. The concentrations of organic acids, however, were lower compared to the concentrations obtained within this study. The difference in results could possibly be attributed to lower concentrations of sodium lactate $(5.0 \mathrm{~g} / \mathrm{L})$ and sodium acetate $(5.0 \mathrm{~g} / \mathrm{L})$ in BB medium. 

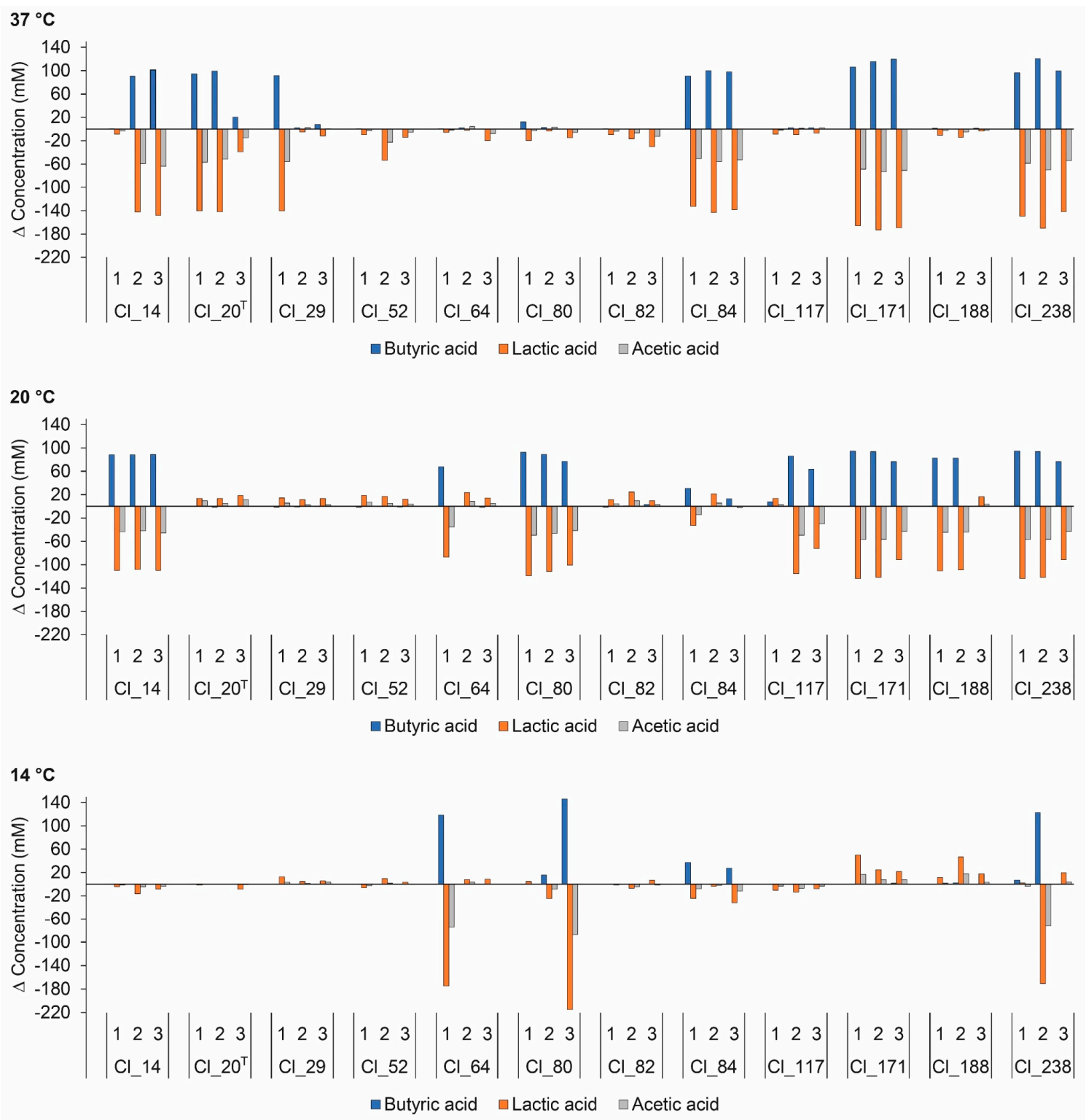

Figure 2. Changes in butyric, lactic, and acetic acid concentrations in enriched milk medium (EM) inoculated with $C$. tyrobutyricum strains after anaerobic incubation at 37,20 , and $14{ }^{\circ} \mathrm{C}$ for 5,28 , and 120 days, respectively. The number under each bar grouping indicates an individual replicate. ${ }^{\mathrm{T}}$ Type strain.

The acetic acid concentration was positively correlated with lactic acid concentration $(r=0.949)$. The observed decrease in acetic acid concentration in replicates with positive gas production indicates its utilization by $C$. tyrobutyricum. Acetic acid is an intermediate on the pathway of lactic acid transformation to butyric acid and can be converted to acetyl-CoA, resulting in higher butyric acid yield [34]. In a study carried out in BB medium, Driehuis et al. reported conversion of acetic acid into butyric acid [33]. Cheeses contaminated with C. tyrobutyricum showed lower levels of acetic acid than control cheese, as reported by Gómez-Torres et al. [35]. On the contrary, Garde et al. reported production of acetic acid in milk inoculated with C. tyrobutyricum strains [12]. Furthermore, raw and pasteurized milk Manchego cheeses with LBD showed higher levels of acetic acids than cheeses without LBD [9], suggesting their production by C. tyrobutyricum.

Propionic acid was detected in very low concentrations within the range of $0.493-5.81 \mathrm{mM}$ (detailed data not shown). However, concentrations of propionic acids were weakly positively correlated with 
gas production $(p<0.01 ; r=0.574)$. Similar results were obtained by Garde et al. for milk contaminated with C. tyrobutyricum isolates under Manchego cheese ripening conditions [12].

Incubation at $14^{\circ} \mathrm{C}$ resulted in significantly $(p<0.05)$ lower changes in organic acid concentrations compared to 37 and $20^{\circ} \mathrm{C}$. However, no significant difference in changes in organic acid concentrations was observed between 37 and $20^{\circ} \mathrm{C}$. These results are consistent with the previous observation that gas production was delayed at temperatures below $20^{\circ} \mathrm{C}$. This observation emphasizes that ripening temperatures have a critical effect on organic acid production and cheese quality.

The conversion of organic acid during ripening of cheese also influences the cheese $\mathrm{pH}$. The extent of $\mathrm{pH}$ change is determined by the amount of organic acid produced and the buffering capacity of the cheese [36]. Figure 3 depicts the changes in $\mathrm{pH}$ values of EM inoculated with $\mathrm{C}$. tyrobutyricum strains. Correlational analysis indicated a positive correlation between the increase of $\mathrm{pH}$ and the amount of gas produced at all temperatures $(p<0.01, r=0.844)$. The $\mathrm{pH}$ change was, as expected, also positively correlated with butyric acid concentration $(r=0.813)$. A pH increase was reported in LBD cheeses made from milk artificially contaminated with clostridial spores $[5,37,38]$, as well as cheeses with natural occurring LBD [9]. The $\mathrm{pH}$ increase is assigned to deacidification arising from the metabolic activity of Clostridium $[5,9,27,35]$. Whereas, for most of the strains, the extent of $\mathrm{pH}$ change was in good agreement with the amount of gas produced, $\mathrm{pH}$ values of replicates of strain $\mathrm{Cl} \_80$ at $20^{\circ} \mathrm{C}$ were not significantly different $(p<0.01)$, although one out of the three replicates significantly differed in gas production.

\subsection{Inoculum Concentration}

The influence of the inoculum concentration of strains $\mathrm{Cl} \_29, \mathrm{Cl} \_84$, and $\mathrm{Cl} \_171$ on the extent of butyric acid fermentation in EM is presented in Figure 4. A significant $(p<0.01)$ delay in gas production in two tested C. tyrobutyricum strains, namely, $\mathrm{Cl} \_29$ and $\mathrm{Cl} \_171$, with reduced inoculum concentration was observed. Accordingly, the butyric acid concentration was higher in EM with increased inoculum concentration. This is in good agreement with the observation of Silvetti et al. who reported faster gas production with higher inoculum levels of $C$. tyrobutyricum under similar conditions [10]. The effect of inoculum on the rate of germination and time to germination has been observed for Clostridium botulinum [39], Bacillus stearothermophilus [40], and Bacillus megaterium [41]. An explanation may be that spores interact with each other and, as they germinate, they release molecules that trigger germination of their dormant neighbors [42]. This was further supported by reports in which growth parameters derived from large inocula were used to stimulate growth from small numbers of spores. The stimulated times to detectable growth were smaller and more homogeneous than the observed detection times, suggesting the communication between the spores $[40,43]$. We also consider the possibility that the bacterial cells could be using a quorum-sensing mechanism to promote the germination, as reported for C. botulinum [44]. However, to the best of our knowledge, no studies have investigated quorum sensing in C. tyrobutyricum.

Surprisingly, the strain Cl_84 showed a different growth behavior when inoculated at the highest inoculum concentration. In fact, only one out of three replicates inoculated with $10^{4}$ spores $/ \mathrm{mL}$ of EM showed gas production at $37^{\circ} \mathrm{C}$, and no gas production was visible at this concentration at 20 and $14{ }^{\circ} \mathrm{C}$. However, at inoculum levels of $10^{3}$ and $10^{2}$ spores $/ \mathrm{mL}$ of EM, the results coincided with the results of $\mathrm{Cl} \_29$ and $\mathrm{Cl} \_171$ insofar as delayed gas production with reduced inoculum concentration was observed at 37,20 , and $14{ }^{\circ} \mathrm{C}$. When the experiment of strain Cl_84 was repeated in EM at 37 ${ }^{\circ} \mathrm{C}$, previous results were confirmed as no gas production was observed for the undiluted spore suspension $\left(10^{4}\right.$ spores $/ \mathrm{mL}$ of EM) but all tubes containing $10^{3}$ and $10^{2}$ spores $/ \mathrm{mL}$ of EM showed gas production. Furthermore, the experiment at $37^{\circ} \mathrm{C}$ was repeated in another medium, namely, reinforced clostridial medium (RCM, Merck, Germany), at inoculum levels of $10^{3}, 10^{4}$, and $10^{5}$ spores $/ \mathrm{mL}$ of RCM. Again, previous results were confirmed as no gas production was observed at an inoculum level of $10^{4}$ spores $/ \mathrm{mL}$ of RCM. However, gas production at a higher concentration $\left(10^{5} \mathrm{spores} / \mathrm{mL}\right.$ of RCM), as well as at a lower level of $10^{3}$ spores/mL of RCM, was observed. According to current knowledge, we 
have no explanation for this germination or growth inhibition effect of strain Cl_84 at the concentration of $10^{4}$ spores/mL of medium.
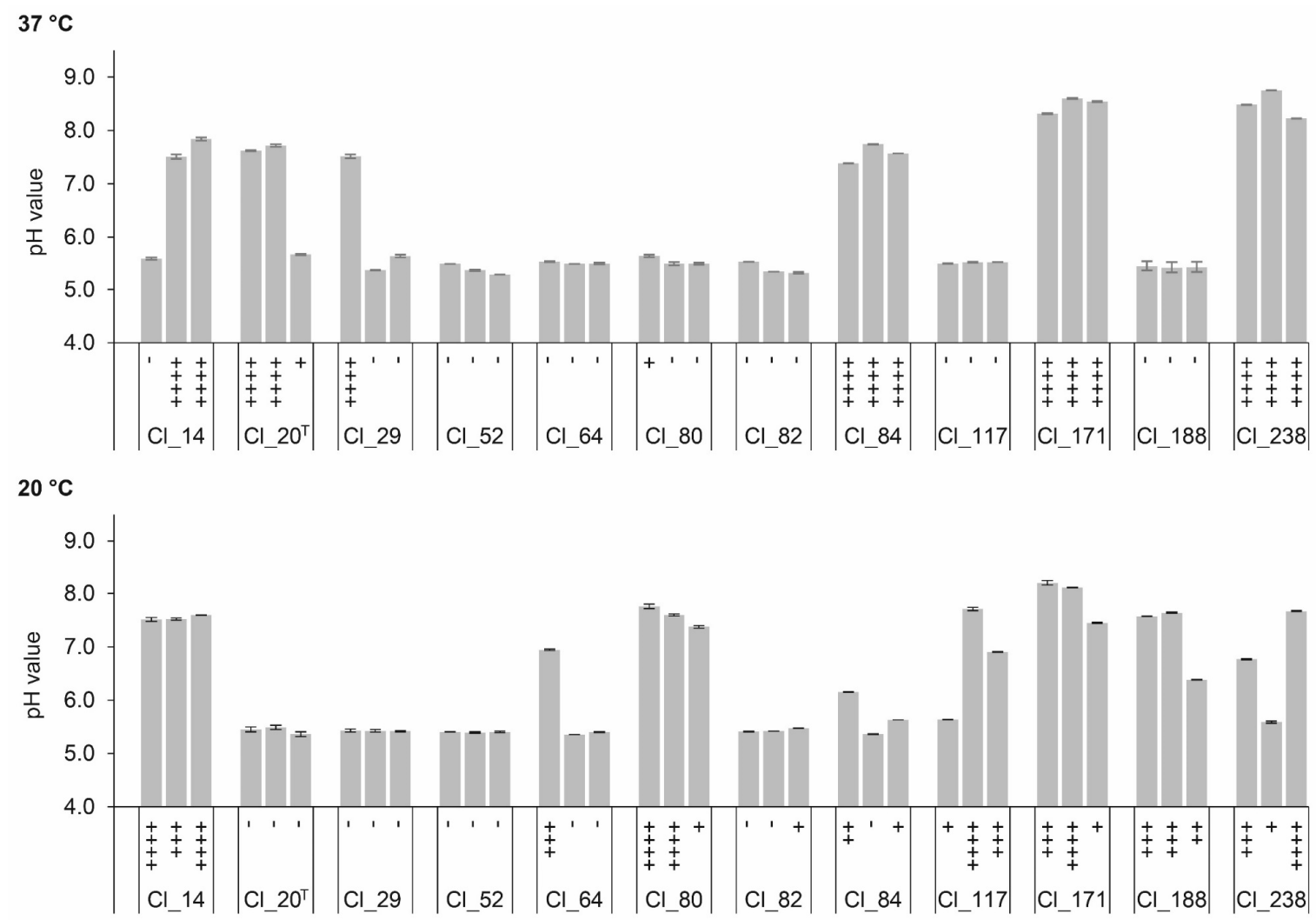

$14{ }^{\circ} \mathrm{C}$

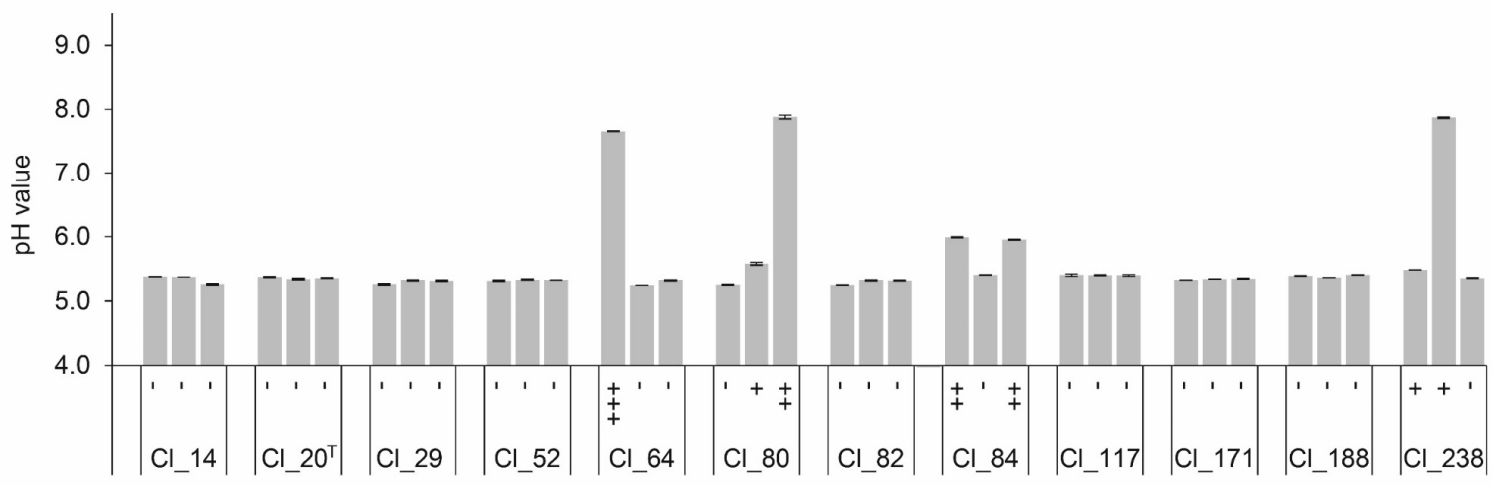

Figure 3. $\mathrm{pH}$ values and gas production in enriched milk medium (EM) inoculated with C. tyrobutyricum strains after anaerobic incubation at 37,20 , and $14{ }^{\circ} \mathrm{C}$ for 5,28 , and 120 days, respectively. The graph shows means of $\mathrm{pH}$ values \pm standard deviations $(n=2)$. Gas production of each replicate is indicated under each bar and expressed as the height of plug displacement in $\mathrm{cm}:(-)<0.5 \mathrm{~cm} ;(+) 0.5-2.9 \mathrm{~cm}$; $(++) 3.0-5.9 \mathrm{~cm} ;(+++) 6.0-8.9 \mathrm{~cm} ;(++++) 9.0-10.0 \mathrm{~cm} .^{\mathrm{T}}$ Type strain.

Overall, the results of this study indicate that the extent of butyric acid fermentation is not only dependent on inoculum concentrations but also driven by characteristics of the individual strains. This hypothesis is also supported by the fact that two of the four strains that produced gas at $14{ }^{\circ} \mathrm{C}$, namely, Cl_64 and Cl_80 (7.2 $\times 10^{1}$ and $8.2 \times 10^{2}$ spores/mL of EM, respectively), were inoculated in lower inoculum concentrations compared to other strains that did not produce gas at this temperature. 


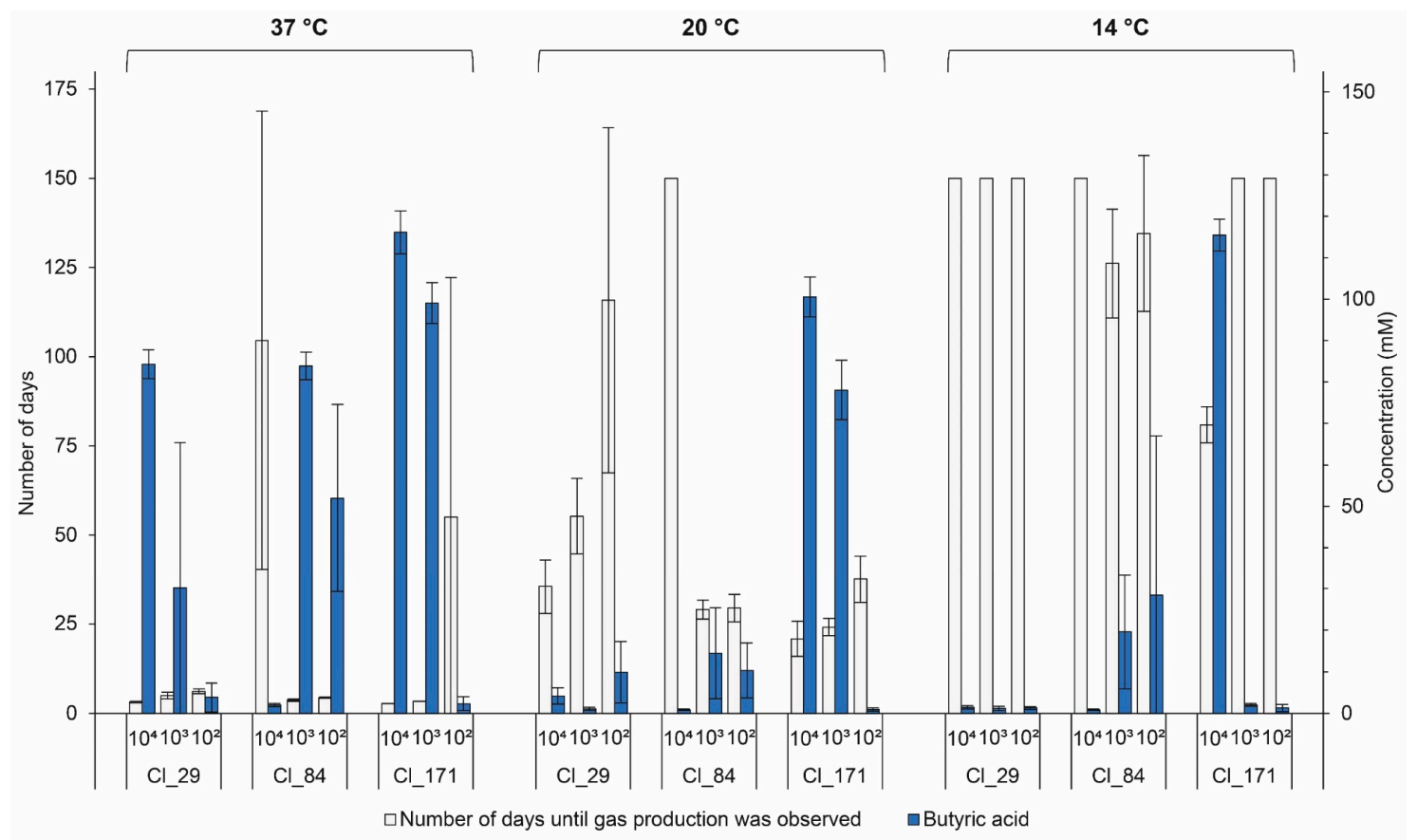

Figure 4. Number of days until gas production and butyric acid concentration in enriched milk medium (EM) inoculated with C. tyrobutyricum strains $\mathrm{Cl} \_29, \mathrm{Cl} \_84$, and $\mathrm{Cl} \_171$ at three different inoculation levels $\left(10^{4}, 10^{3}\right.$, and $10^{2}$ spores/mL EM) during anaerobic incubation at 37,20 , and $14{ }^{\circ} \mathrm{C}$. Butyric acid concentration was determined after 5,28 , and 120 days of anaerobic incubation at 37,20 , and $14{ }^{\circ} \mathrm{C}$, respectively. Each bar represents the mean \pm standard deviation $(n=3)$.

\subsection{Phenotypic Diversity}

The capability to produce gas and organic acids is considered to be a characteristic of $C$. tyrobutyricum $[3,5,6,45]$. Several differences in growth behavior, as well as gas and organic acid production, have been observed that cannot be exclusively attributed to different inoculum levels but rather to strain-dependent variability.

For instance, gas production of the type strain $\mathrm{Cl} \_20$ at $37^{\circ} \mathrm{C}$ was faster, but growth at $20^{\circ} \mathrm{C}$ was significantly slower compared to other strains, and, at $14{ }^{\circ} \mathrm{C}$, no growth was detected at all. This observation suggests that the type strain, in contrast to milk and cheese isolates, may not be adapted to lower temperatures and may be displaying a less active metabolism than wild-type isolates. Another strain, namely, $\mathrm{Cl} \_29$, also showed faster outgrowth at $37^{\circ} \mathrm{C}$, but slower growth at $20^{\circ} \mathrm{C}$ in comparison to other strains and no growth at all at $14{ }^{\circ} \mathrm{C}$. This is in good agreement with the highly similar genotypes of strains $\mathrm{Cl} \_20$ and $\mathrm{Cl} \_29$ obtained using hexaplex-PCR typing (Figure 1b). Moreover, these two strains were grouped into the same cluster in the dendrogram according to MALDI-TOF MS spectra (Figure 1a). Furthermore, strain $\mathrm{Cl} \_14$ also showed fast outgrowth at $37^{\circ} \mathrm{C}$ and no growth at $14{ }^{\circ} \mathrm{C}$, but faster growth at $20^{\circ} \mathrm{C}$ compared to $\mathrm{Cl} \_20$ and Cl_29. This strain also clustered in proximity to $\mathrm{Cl} \_20$ in both dendrograms in Figure 1a,b.

In contrast to $\mathrm{Cl} \_20, \mathrm{Cl} \_29$, and $\mathrm{Cl} \_14$, several milk and cheese isolates showed slower growth at $37^{\circ} \mathrm{C}$ than other strains, but faster growth at $20^{\circ} \mathrm{C}\left(\mathrm{Cl} \_117, \mathrm{Cl} \_188, \mathrm{Cl} \_64\right.$, and $\left.\mathrm{Cl} \_80\right)$. Indeed, $\mathrm{Cl} \_64$ and $\mathrm{Cl} \_80$ were among the four strains that were able to produce gas at $14{ }^{\circ} \mathrm{C}$ within the 170 day test period indicating extraordinary adaptation to low temperatures. Although $\mathrm{Cl} \_64$ and $\mathrm{Cl} \_80$ showed similar phenotypic characteristics, low similarity was observed between their MALDI-TOF MS spectra, as well as their hexaplex-PCR fingerprints (Figure 1a,b). Interestingly, $\mathrm{Cl}$ 664 clustered separately from other strains in the MALDI-TOF MS analysis, but showed high similarity with many other isolates in hexaplex-PCR fingerprinting (Figure 1b). 
Only four out of 12 strains $\left(C l \_64, C l \_80, C l \_84\right.$, and $\left.C l \_238\right)$ were able to produce gas at each of the three tested temperatures. However, genetic similarity did not become apparent within this group in the dendrogram.

Although two strains $\left(\mathrm{Cl} \_82\right.$ and $\left.\mathrm{Cl} \_84\right)$ were isolated from raw milk obtained from the same production location, $\mathrm{Cl} \_82$ showed slower gas production at $20{ }^{\circ} \mathrm{C}$ compared to $\mathrm{Cl} \_84$ and no gas production at all at 37 and $14{ }^{\circ} \mathrm{C}$. These two strains were also distributed in different clusters in the dendrogram according to hexaplex-PCR fingerprints but fell within the same cluster in the MALDI-TOF MS analysis (Figure 1a,b). Strain $\mathrm{Cl} \_238$ was isolated from the same production location as $\mathrm{Cl} \_82$ and Cl_84, but 1 year earlier. Within both dendrograms, it clustered separately from $\mathrm{Cl} \_82$ and $\mathrm{Cl} \_84$.

One strain, namely, $\mathrm{Cl} \_52$, did not show any metabolic activity at all. Even when the concentration of the spore inoculum was determined, this strain did not produce colonies on RCA (Table 1). Nevertheless, strain Cl_52 was included into the experiment due to its characteristic growth behavior in preliminary experiments (data not shown). $\mathrm{Cl}$ 552 had exhibited slower growth than other $C$. tyrobutyricum strains on RCA ( 5 days compared to 2 days). Furthermore, this strain clustered far from most of the other strains using the two typing methods within this study (Figure 1a,b) and GTG-5 typing [8]. To ensure the presence of the microorganism, phase-contrast microscopy of the spore suspension was performed and revealed that, indeed, the overall cell density of the spore suspension was lower compared to other strains of the test panel. Furthermore, the bacterium also appeared to be in a different state (Figure S1d, Supplementary Materials). Spores of Cl_52 were mostly visible within the vegetative cells suggesting that the development of free spores may not have been completed under the chosen incubation conditions. For another strain $\left(\mathrm{Cl}_{-} 82\right)$, no colonies were produced on RCA when the concentration of the spore suspension was determined. The presence of spores, however, was confirmed using phase-contrast microscopy, in which a higher number of vegetative cells than spores was observed (Figure S1g, Supplementary Materials).

The results of this study show that different strains of $C$. tyrobutyricum vary in their ability to form spores and subsequently germinate in vitro. Our findings are consistent with those on C. botulinum, i.e., that germination is dependent on the strain, presumably due to the strain-specific germinant specificity [46]. One possible explanation for the high heterogeneity among the tested strains could be impaired germination of spores rather than decreased ability of germinated spores to form butyric acid and gases [3].

The fact that spore formation is strictly related to environmental stress may affect the ability of $C$. tyrobutyricum to germinate and grow at lower temperatures [47]. While many studies clarified the conditions that affect $C$. tyrobutyricum growth at reduced temperatures, no work has been done to characterize the specific molecular components and their roles that allow such growth to occur [48-50]. It is likely that, according to the mechanisms of other related spore-formers, membrane fatty acid components are altered to increase fluidity, and RNA stability mechanisms are involved [51]. The obtained results indicate that some strains may be adapted to lower temperatures, suggesting strain-specific adaptation mechanisms.

However, although we observed several strain-dependent effects, we also noticed great variation in butyric acid fermentation ability within the replicates of the same strain despite a homogeneous and a common inoculum. For instance, only two of three replicates of strain Cl_64 produced gas at $37^{\circ} \mathrm{C}$, while only one of three replicates produced gas at $14^{\circ} \mathrm{C}$ (Table 2). Furthermore, particularly replicates of strains that were inoculated at low concentrations $\left(\mathrm{Cl} \_64, \mathrm{Cl} \_80, \mathrm{Cl} \_82, \mathrm{Cl}\right.$ _117) exhibited high heterogeneity in time spans until gas production was observed. Possible reasons for the observed heterogeneity may be distinct amounts of germination receptors per spore, germination commitment, or the subsequent stages of germination, outgrowth, and vegetative growth $[49,52,53]$. Because a greater percentage of rapid-germinating spores is expected at higher spore densities, the apparent spore germination of a population may be associated with inoculum size [41]. It is also possible that a small fragment of spore population, termed superdormant spores, may exhibit extremely long and unpredictable germination and outgrowth responses or not respond to known 
germination triggers [49]. Previous studies on different Clostridium species, C. perfringens, C. botulinum, and Clostridioides (Clostridium) difficile, demonstrated that the presence of superdormant spores also contributes to germination heterogeneity [50,54-56]. To the best of our knowledge, no work has been focused on C. tyrobutyricum.

On the basis of the varying germination behaviors observed in this study, we conclude that some of the tested strains may pose a higher risk for cheese spoilage than others. Four strains $\left(\mathrm{Cl}_{-} 64, \mathrm{Cl} \_80\right.$, $\mathrm{Cl} \_84$, and $\mathrm{Cl}$ 238) germinated and produced gas at each of the tested temperatures including the temperature of $14^{\circ} \mathrm{C}$. As this temperature is close to the temperatures occurring during cheese ripening, this group of strains may constitute a high risk for late blowing defects. However, it is important to point out that strain $\mathrm{Cl} \_84$ did not produce gas at the spore concentration of $10^{4}$ spores/mL of EM but at every other tested concentration level. Some strains $\left(\mathrm{Cl} \_14, \mathrm{Cl}\right.$ 117, $\mathrm{Cl} \_171$, and $\left.\mathrm{Cl} \_188\right)$ may be considered as an "intermediate risk" because these strains did not grow at $14{ }^{\circ} \mathrm{C}$ but showed good growth at $20^{\circ} \mathrm{C}$. A low risk for cheese spoilage is expected from strains Cl_20 and Cl_29, as well as $\mathrm{Cl} \_82$, because these strains showed no growth at $14{ }^{\circ} \mathrm{C}$ and slow outgrowth at $20^{\circ} \mathrm{C}$. Because $\mathrm{Cl} 552$ showed no metabolic activity in any of the tested conditions, this strain seems to pose a very low risk for cheese spoilage. Of course, it is important to consider that the spoilage potential of the tested strains may be different in cheese for several reasons. Raw milk and cheese, for instance, provide a complex habitat for different microorganisms that may interact with clostridia and vice versa. Several authors highlighted the synergistic effect between clostridial species and/or strains [3,5,32], whereas lactobacilli and some related bacteria may inhibit the growth of $C$. tyrobutyricum by producing different antibiotic compounds [26,57].

\section{Conclusions}

In conclusion, the present study supports the hypothesis that cheese spoilage may be not only dependent on clostridial spore concentrations but also on characteristics of individual C. tyrobutyricum strains. Across the tested strain set, we observed high genotypic and moderate proteotypic diversity. Some of the genotypic and proteotypic differences and similarities also manifested themselves in phenotypic traits, such as germination and gas formation at different temperatures. However, variations were not only detected among the tested strains but also among replicates of the same strain. This indicates that differences within populations of the same strain and developmental stages of single cells and spores also may be relevant.

This study provides interesting insights into strain-dependent germination and gas formation of C. tyrobutyricum. The results indicate that some strains of this species may be more relevant for cheese spoilage than others. The findings obtained in this experimental setting may serve as a basis for future studies in cheese. In addition, genomic and transcriptomic research is encouraged to enhance our understanding of the genetic background of the observed phenotypic differences among C. tyrobutyricum strains.

Supplementary Materials: The following are available online at http://www.mdpi.com/2076-2607/8/11/1836/s1: Figure S1. Phase-contrast microscope images of 12 spore suspensions of C. tyrobutyricum strains: (a) Cl_14; (b) Cl_20 (type strain; dilution 1:10); (c) Cl_29; (d) Cl_52; (e) Cl_64 (dilution 1:10); (f) Cl_80 (dilution 1:10); (g) Cl_82 (dilution 1:10); (h) Cl_84; (i) Cl_117; (j) Cl_171 (dilution 1:10); (k) Cl_188 (dilution 1:10); and (l) Cl_238. The spore suspensions are observed under $1000 \times$ magnification with oil under a phase-contrast microscope. Scale bars indicate $10 \mu \mathrm{m}$.

Author Contributions: Conceptualization, J.B. and K.J.D.; methodology, J.B. and K.J.D.; formal analysis, L.P. and J.B.; investigation, L.P. and F.K.; writing—original draft preparation, L.P. and J.B.; writing-review and editing, J.B. and K.J.D.; visualization, L.P. and J.B.; supervision, J.B. and K.J.D.; project administration, K.J.D. and J.B.; funding acquisition, K.J.D. and J.B. All authors read and agreed to the published version of the manuscript.

Funding: This work was created within a research project of the Austrian Competence Center for Feed and Food Quality, Safety and Innovation (FFoQSI GmbH). The COMET-K1 competence centre FFoQSI is funded by the Austrian ministries BMVIT and BMDW and the Austrian provinces Niederoesterreich, Upper Austria, and Vienna within the scope of COMET-Competence Centers for Excellent Technologies. The program COMET is 
handled by the Austrian Research Promotion Agency FFG. Furthermore, this study was partly funded by the Hochschuljubiläumsstiftung of the city of Vienna (project number 274597/2018).

Acknowledgments: The authors thank the EQ BOKU VIBT GmbH-Center for Preservation and Aseptic Processing for providing the MALDI-TOF MS Bruker Biotyper. The authors would also like to thank Cindy Lorenz, Lisa-Maria Call, and Stefano D'Amico for their support during the HPLC analysis.

Conflicts of Interest: The authors declare no conflict of interest.

\section{References}

1. Brändle, J.; Domig, K.J.; Kneifel, W. Relevance and analysis of butyric acid producing clostridia in milk and cheese. Food Control 2016, 67, 96-113. [CrossRef]

2. Doyle, C.J.; Gleeson, D.; Jordan, K.; Beresford, T.P.; Ross, R.P.; Fitzgerald, G.F.; Cotter, P.D. Anaerobic sporeformers and their significance with respect to milk and dairy products. Int. J. Food Microbiol. 2015, 197, 77-87. [CrossRef] [PubMed]

3. Klijn, N.; Nieuwenhof, F.F.J.; Hollwerf, J.D.; Vanderwaals, C.B.; Weerkamp, A.H. Identification of Clostridium tyrobutyricum as the causative agent of late blowing in cheese by species-specific PCR amplification. Appl. Environ. Microbiol. 1995, 61, 2919-2924. [CrossRef] [PubMed]

4. Julien, M.C.; Dion, P.; Lafreniere, C.; Antoun, H.; Drouin, P. Sources of clostridia in raw milk on farms. Appl. Environ. Microbiol. 2008, 74, 6348-6357. [CrossRef] [PubMed]

5. Le Bourhis, A.-G.; Doré, J.; Carlier, J.-P.; Chamba, J.-F.; Popoff, M.-R.; Tholozan, J.-L. Contribution of C. beijerinckii and C. sporogenes in association with C. tyrobutyricum to the butyric fermentation in Emmental type cheese. Int. J. Food Microbiol. 2007, 113, 154-163. [CrossRef] [PubMed]

6. Brändle, J.; Fraberger, V.; Berta, J.; Puglisi, E.; Jami, M.; Kneifel, W.; Domig, K.J. Butyric acid producing clostridia in cheese-Towards the completion of knowledge by means of an amalgamate of methodologies. Int. Dairy J. 2018, 86, 86-95. [CrossRef]

7. Bermúdez, J.; González, M.J.; Olivera, J.A.; Burgueño, J.A.; Juliano, P.; Fox, E.M.; Reginensi, S.M. Seasonal occurrence and molecular diversity of clostridia species spores along cheesemaking streams of 5 commercial dairy plants. J. Dairy Sci. 2016, 99, 3358-3366. [CrossRef]

8. Burtscher, J.; Küller, F.; Dreier, M.; Arias-Roth, E.; Drissner, D.; Domig, K.J. Characterization of Clostridium tyrobutyricum strains using three different typing techniques. Microorganisms 2020, 8, 1057. [CrossRef]

9. Garde, S.; Ávila, M.; Gaya, P.; Arias, R.; Nuñez, M. Sugars and organic acids in raw and pasteurized milk Manchego cheeses with different degrees of late blowing defect. Int. Dairy J. 2012, 25, 87-91. [CrossRef]

10. Silvetti, T.; Morandi, S.; Brasca, M. Growth factors affecting gas production and reduction potential of vegetative cell and spore inocula of dairy-related Clostridium species. LWT 2018, 92, 32-39. [CrossRef]

11. Ruusunen, M.; Surakka, A.; Korkeala, H.; Lindström, M. Clostridium tyrobutyricum strains show wide variation in growth at different $\mathrm{NaCl}, \mathrm{pH}$, and temperature conditions. J. Food Prot. 2012, 75, 1791-1795. [CrossRef] [PubMed]

12. Garde, S.; Arias, R.; Gaya, P.; Nuñez, M. Occurrence of Clostridium spp. in ovine milk and Manchego cheese with late blowing defect: Identification and characterization of isolates. Int. Dairy J. 2011, 21, 272-278. [CrossRef]

13. Brändle, J.; Heinzle, L.; Fraberger, V.; Berta, J.; Zitz, U.; Schinkinger, M.; Stocker, W.; Kneifel, W.; Domig, K.J. Novel approach to enumerate clostridial endospores in milk. Food Control 2018, 85, 318-326. [CrossRef]

14. D’Incecco, P.; Pellegrino, L.; Hogenboom, J.A.; Cocconcelli, P.S.; Bassi, D. The late blowing defect of hard cheeses: Behaviour of cells and spores of Clostridium tyrobutyricum throughout the cheese manufacturing and ripening. LWT 2018, 87, 134-141. [CrossRef]

15. Anonymous. Vorarlberger Bergkäse g.U. Annex I Council Regulation (EEC) No 2081/92. Available online: https://ec.europa.eu/agriculture/quality/door/registeredName.html?denominationId=777 (accessed on 23 April 2020).

16. Anonymous. Tiroler Bergkäse g.U. Council Regulation (EEC) No 2081/92. Available online: https://ec.europa. eu/agriculture/quality/door/registeredName.html?denominationId=705 (accessed on 23 April 2020).

17. Guinee, T.P.; Fox, P.F. Chapter 13-Salt in Cheese: Physical, Chemical and Biological Aspects. In Cheese, 4th ed.; McSweeney, P.L.H., Fox, P.F., Cotter, P.D., Everett, D.W., Eds.; Academic Press: San Diego, CA, USA, 2017; Volume 1, pp. 317-375, ISBN 978-0-12-417012-4. 
18. Rainey, F.A.; Hollen, B.J.; Small, A.M. Clostridium. In Bergey's Manual of Systematics of Archaea and Bacteria; Whitman, W.B., Rainey, F., Kämpfer, P., Trujillo, M., Chun, J., DeVos, P., Hedlund, B., Dedysh, S., Eds.; John Wiley \& Sons, Inc., in Association with Bergey‘s Manual Trust: New York, NY, USA, 2015; pp. 1-122, ISBN 9781118960608. [CrossRef]

19. Bachmann, H.P.; Bütikofer, U.; Fröhlich-Wyder, M.T.; Isolini, D.; Jakob, E. Cheese | Swiss-Type Cheeses. In Encyclopedia of Dairy Sciences, 2nd ed.; Fuquay, J.W., Ed.; Academic Press: San Diego, CA, USA, 2011; pp. 712-720, ISBN 978-0-12-374407-4.

20. Su, Y.-C.; Ingham, S.C. Influence of milk centrifugation, brining and ripening conditions in preventing gas formation by Clostridium spp. in Gouda cheese. Int. J. Food Microbiol. 2000, 54, 147-154. [CrossRef]

21. Morandi, S.; Battelli, G.; Silvetti, T.; Tringali, S.; Nunziata, L.; Villa, A.; Acquistapace, A.; Brasca, M. Impact of salting and ripening temperatures on late blowing defect in Valtellina Casera PDO cheese. Food Control 2021, 120, 107508. [CrossRef]

22. Burtscher, J.; Hobl, L.; Kneifel, W.; Domig, K.J. Short communication: Clostridial spore counts in vat milk of Alpine dairies. J. Dairy Sci. 2020, 103, 2111-2116. [CrossRef] [PubMed]

23. Arias, C.; Oliete, B.; Seseña, S.; Jimenez, L.; Pérez-Guzmán, M.D.; Arias, R. Importance of on-farm management practices on lactate-fermenting Clostridium spp. spore contamination of Manchega ewe milk: Determination of risk factors and characterization of Clostridium population. Small Rumin. Res. 2013, 111, 120-128. [CrossRef]

24. Zucali, M.; Bava, L.; Colombini, S.; Brasca, M.; Decimo, M.; Morandi, S.; Tamburini, A.; Crovetto, G.M. Management practices and forage quality affecting the contamination of milk with anaerobic spore-forming bacteria. J. Sci. Food Agric. 2015, 95, 1294-1302. [CrossRef]

25. Klantschitsch, T. Influence of Microfiltration on the Quality of Semi-Hard Cheese from Raw Milk with Particular Emphasis on Clostridium tyrobutyricum Spores. Ph.D.Thesis, Swiss Federal Institute of Technology (ETH), Zürich, Switzerland, 1999.

26. Ávila, M.; Gómez-Torres, N.; Hernández, M.; Garde, S. Inhibitory activity of reuterin, nisin, lysozyme and nitrite against vegetative cells and spores of dairy-related Clostridium species. Int. J. Food Microbiol. 2014, 172, 70-75. [CrossRef]

27. Bogovič Matijašić, B.; Koman Rajšp, M.; Perko, B.; Rogelj, I. Inhibition of Clostridium tyrobutyricum in cheese by Lactobacillus gasseri. Int. Dairy J. 2007, 17, 157-166. [CrossRef]

28. Cosentino, C.; Paolino, R.; Valentini, V.; Musto, M.; Ricciardi, A.; Adduci, F.; D'Adamo, C.; Pecora, G.; Freschi, P. Effect of jenny milk addition on the inhibition of late blowing in semihard cheese. J. Dairy Sci. 2015, 98, 5133-5142. [CrossRef] [PubMed]

29. Stadhouders, J. Prevention of butyric acid fermentation by the use of nitrate. Bull. Int. Dairy Fed. 1990, 251, 40-46.

30. Fox, P.F.; Lucey, J.A.; Cogan, T.M. Glycolysis and related reactions during cheese manufacture and ripening. Crit. Rev. Food Sci. Nutr. 1990, 29, 237-253. [CrossRef] [PubMed]

31. Fox, P.F.; Law, J.; McSweeney, P.L.H.; Wallace, J. Biochemistry of Cheese Ripening. In Cheese: Chemistry, Physics and Microbiology: Volume 1 General Aspects; Fox, P.F., Ed.; Springer: Boston, MA, USA, 1993; pp. 389-438, ISBN 978-1-4615-2650-6.

32. Jakob, E. Buttersäureblähung-noch immer aktuell. Proc. ALP Forum 2005, 20, 1-18.

33. Driehuis, F.; Hoolwerf, J.; Rademaker, J.L.W. Concurrence of spores of Clostridium tyrobutyricum, Clostridium beijerinckii and Paenibacillus polymyxa in silage, dairy cow faeces and raw milk. Int. Dairy J. 2016, 63, 70-77. [CrossRef]

34. Lee, J.; Jang, Y.-S.; Han, M.-J.; Kim, J.Y.; Lee, S.Y. Deciphering Clostridium tyrobutyricum metabolism based on the whole-genome sequence and proteome analyses. mBio 2016, 7, e00743-00716. [CrossRef]

35. Gómez-Torres, N.; Garde, S.; Peirotén, A.; Ávila, M. Impact of Clostridium spp. on cheese characteristics: Microbiology, color, formation of volatile compounds and off-flavors. Food Control 2015, 56, 186-194. [CrossRef]

36. Lucey, J.A.; Fox, P.F. Importance of calcium and phosphate in cheese manufacture: A review. J. Dairy Sci. 1993, 76, 1714-1724. [CrossRef]

37. Borreani, G.; Ferrero, F.; Nucera, D.; Casale, M.; Piano, S.; Tabacco, E. Dairy farm management practices and the risk of contamination of tank milk from Clostridium spp. and Paenibacillus spp. spores in silage, total mixed ration, dairy cow feces, and raw milk. J. Dairy Sci. 2019, 102, 8273-8289. [CrossRef] 
38. Garde, S.; Ávila, M.; Arias, R.; Gaya, P.; Nuñez, M. Outgrowth inhibition of Clostridium beijerinckii spores by a bacteriocin-producing lactic culture in ovine milk cheese. Int. J. Food Microbiol. 2011, 150, 59-65. [CrossRef] [PubMed]

39. Zhao, L.; Montville, T.J.; Schaffner, D.W. Inoculum size of Clostridium botulinum 56A spores influences time-to-detection and percent growth-positive samples. J. Food Sci. 2000, 65, 1369-1375. [CrossRef]

40. Llaudes, M.K.; Zhao, L.; Duffy, S.; Schaffner, D.W. Simulation and modelling of the effect of small inoculum size on time to spoilage by Bacillus stearothermophilus. Food Microbiol. 2001, 18, 395-405. [CrossRef]

41. Caipo, M.L.; Duffy, S.; Zhao, L.; Schaffner, D.W. Bacillus megaterium spore germination is influenced by inoculum size. J. Appl. Microbiol. 2002, 92, 879-884. [CrossRef] [PubMed]

42. Webb, M.D.; Stringer, S.C.; Le Marc, Y.; Baranyi, J.; Peck, M.W. Does proximity to neighbours affect germination of spores of non-proteolytic Clostridium botulinum? Food Microbiol. 2012, 32, 104-109. [CrossRef]

43. Zhao, L.; Montville, T.J.; Schaffner, D.W. Computer simulation of Clostridium botulinum strain 56A behavior at low spore concentrations. Appl. Environ. Microbiol. 2003, 69, 845-851. [CrossRef]

44. Zhao, L.; Montville, T.J.; Schaffner, D.W. Evidence for quorum sensing in Clostridium botulinum 56A. Lett. Appl. Microbiol. 2006, 42, 54-58. [CrossRef]

45. Le Bourhis, A.-G.; Saunier, K.; Doré, J.; Carlier, J.-P.; Chamba, J.-F.; Popoff, M.-R.; Tholozan, J.-L. Development and validation of PCR primers to assess the diversity of Clostridium spp. in cheese by temporal temperature gradient gel electrophoresis. Appl. Environ. Microbiol. 2005, 71, 29-38. [CrossRef]

46. Alberto, F.; Broussolle, V.; Mason, D.R.; Carlin, F.; Peck, M.W. Variability in spore germination response by strains of proteolytic Clostridium botulinum types A, B and F. Lett. Appl. Microbiol. 2003, 36, 41-45. [CrossRef]

47. Tanner, F.W.; Oglesby, E.W. Influence of temperature on growth and toxin production by Clostridium botulinum. J. Food Sci. 1936, 1, 481-494. [CrossRef]

48. Setlow, P.; Liu, J.; Faeder, J.R. Heterogeneity in bacterial spore populations. In Bacterial Spores: Current Research and Applications; Abel-Santos, A., Ed.; Caister Academic Press: Norfolk, UK, 2012; pp. 199-214.

49. Setlow, P.; Wang, S.; Li, Y.-Q. Germination of spores of the orders Bacillales and Clostridiales. Annu. Rev. Microbiol. 2017, 71, 459-477. [CrossRef] [PubMed]

50. Stringer, S.C.; Webb, M.D.; Peck, M.W. Lag time variability in individual spores of Clostridium botulinum. Food Microbiol. 2011, 28, 228-235. [CrossRef] [PubMed]

51. Checinska, A.; Paszczynski, A.; Burbank, M. Bacillus and other spore-forming genera: Variations in responses and mechanisms for survival. Annu. Rev. Food Sci. Technol. 2015, 6, 351-369. [CrossRef] [PubMed]

52. Luu, S.; Setlow, P. Analysis of the loss in heat and acid resistance during germination of spores of Bacillus species. J. Bacteriol. 2014, 196, 1733-1740. [CrossRef]

53. Pandey, R.; Ter Beek, A.; Vischer, N.O.E.; Smelt, J.P.P.M.; Brul, S.; Manders, E.M.M. Live cell imaging of germination and outgrowth of individual Bacillus subtilis spores; the effect of heat stress quantitatively analyzed with SporeTracker. PLoS ONE 2013, 8, e58972. [CrossRef]

54. Deng, K.; Talukdar, P.K.; Sarker, M.R.; Paredes-Sabja, D.; Torres, J.A. Survival of Clostridium difficile spores at low water activity. Food Microbiol. 2017, 65, 274-278. [CrossRef]

55. Wang, G.; Paredes-Sabja, D.; Sarker, M.R.; Green, C.; Setlow, P.; Li, Y.-Q. Effects of wet heat treatment on the germination of individual spores of Clostridium perfringens. J. Appl. Microbiol. 2012, 113, 824-836. [CrossRef]

56. Zhang, Y.; Mathys, A. Superdormant spores as a hurdle for gentle germination-inactivation based spore control strategies. Front. Microbiol. 2019, 9. [CrossRef]

57. Rilla, N.; Martinez, B.; Delgado, T.; Rodriguez, A. Inhibition of Clostridium tyrobutyricum in Vidiago cheese by Lactococcus lactis ssp. lactis IPLA 729, a nisin Z producer. Int. J. Food Microbiol. 2003, 85, 23-33. [CrossRef]

Publisher's Note: MDPI stays neutral with regard to jurisdictional claims in published maps and institutional affiliations. 